\title{
The new commodities of the new media landscape
}

Book

\section{Reviewed by}

Abstract

Keywords

What's the book about?
Graham, G., Greenhill, A., Shaw, D. And Vargo, C., eds. (2015) Content is King: NeWs Media Management in the Digital Age. LONDON, U.K.: BLOOMSBURY

\section{Andy Ridgway}

The 'traditional' media industry - newspapers and magazines and the like - have had a difficult time lately thanks to increasing competition online. This book's chapters consider ways the traditional media can reinvent themselves to secure their future. Two key themes that emerge from the chapters are the importance of building communities and the increasing role of credibility in today's highly-competitive media landscape. While this book does not focus on the science media, many of the conclusions are relevant to it, in fact some are cause for comfort for those involved with science journalism.

Popularization of science and technology; Science and media; Science writing

Back in 2006, Time magazine chose 'You' as the person of the year. While you may not have been aware of the honour bestowed on you until now, it was. And it's all down to the contribution that you, and me, and everyone else makes to the font of knowledge that is the internet, via YouTube, Wikipedia and the like. Now, as anyone involved with the media industry in the past decade or so knows, this democratization of communication has led to certain challenges. Not least of which are declining circulations and redundancies as consumers have sought their news from new online sources.

This book, a collection of chapters by a collection of academics, is an attempt to understand how the digital revolution has affected the media industry and, more importantly, offer solutions. One thing to make clear is that this book does not focus in any way on science journalism and science writing. In fact, aside from a chapter that explores what science fiction might tell us about the future of the media industry (quite a lot as it turns out - more on that later), the word 'science' is not mentioned once.

But, much of what is said in its pages applies equally well to the science writing industry as it does to the local and national non-specialist print media, which are 
the focus of the book. In fact, some of the conclusions here should be a cause for comfort for anyone involved with science journalism.

Who is the book for?

What is it like?
This book nails its flag to the mast in the first chapter, stating explicitly that it is aimed at 'those who manage or hope to manage news media' — including students. While there is much straightforward analysis and practical advice in its pages for practitioners, some chapters feel quite theoretical and abstract. The result is likely to be a rather mixed bag of usefulness for the stated target audience. At the same time, some of the detailed practicalities of publishing explored in the book (such as the ins and outs of finding a suitable production slot when a digital publisher decides to venture into print) are likely to leave the academic reader cold.

In an outstanding chapter on disruptive technology, Chris Vargo at the University of Alabama and Donald Shaw at the University of North Carolina at Chapel Hill explore the lessons that can be learned by the media industry from disruptive innovation theory [Christensen, 2011]. This theory holds that media companies have failed to invest in emerging media techniques such as microblogging, user-generated content and sponsored content because of the low financial returns that these services offer. Most of the value of these services, such as convenience and low cost, are benefits for the consumer.

Vargo and Shaw say that some observers suggest that when a disruptive technology rises, the old incumbents - traditional media in this instance disappear. But, they say, Ahlers [2006] notes that the disruptive media have not replaced the traditional media to the extent that had been predicted. Vargo and Shaw suggest that the key function that news media have provided is community and the desire for community has not changed on the part of consumers. What has changed is that the new 'digital disruptors' - Twitter, Facebook and the like - do it better. And where once community was geographically defined, new communication technologies allow consumers to choose from a wider range of communities - ones that allow them to explore their interests. The key then, say Vargo and Shaw, is that the media must find these communities and engage with them effectively; create demand for what they have to say. Once there's demand, that's when payments come through the likes of YouTube and Facebook.

Sounds straightforward. But creating demand like this requires attrition and a few failures along the way. Vargo and Shaw acknowledge that this process is "prone to trial and error" and earlier in the chapter that even the new cool kids on the block, such as the mighty Google, get it wrong sometimes - Google Buzz and Google Wave being examples of ideas that did not stand the test of time.

The diversity of the chapter authors adds diversity to the opinions and ideas suggested. In chapter 9, Mikko Sihvonen at Manchester Metropolitan University and Seamus Simpson at the University of Salford state that digital technology "... have developed in a context wherein economic imperatives have assumed primacy over journalistic standards." (p. 158). To mitigate this they suggest public subsidies for news that has "intrinsic public value" as well as a publically funded large, well resourced "public-service media operator" (the BBC comes to mind). In 
other words, we can't rely on market forces to give us important services like investigative journalism and overseas news reporting.

The downside of this eclectic authorship of chapters is that it leads to some frustrating repetition at the beginning of chapters as each authoring team sets the context for their analysis. We read on more than one occasion that the media landscape has changed over the past decade or so. But that's not to say that this book does not contain insightful comment and analysis. There are also some themes that tellingly crop up repeatedly in the chapters.

One of which is the importance of credibility in this new media landscape - both of the media organisations and the journalists who work for them. In chapter 12, Gary Graham at Leeds University Business School, Anita Greenhill at the University of Manchester and Maria Jose Hernandez Serrano at the University of Salamanca, Spain, report the results of interviews with news organisations in the UK. Most insightful are the interviews with one local news publication, News Chronicle, which has shifted its "value-creation strategy from attention to trust". Where printed newspapers have relied on creating attention to maintain their business, this has lost its relevance as news of incidents travels faster via the likes of Twitter than conventional means. "However trust can be understood to be a scarce resource," say the authors. They say the News Chronicle's ultimate aim is to build itself into a "trusted data hub".

There are some useful thoughts earlier in the book about what that means at an individual level. Chris Vargo, in chapter 10, citing Weimann [1991; 1994], says that opinion leaders on social media are not necessarily celebrities, they can also be "those that ordinary people turn to for information and advice." (p. 167). So these opinion leaders, says Vargo, can be journalists. "Encouraging journalists not to act like a celebrity on Twitter but instead as a constant, reliable source of quality information makes them valuable." (p. 167). While Vargo's focus

- understandably given the emphasis of the book - is on local news, this lesson is important for any journalist, including science journalists.

So in short, the key messages from this book revolve around engaging with the new communities that have emerged online and creating trust within those communities, so you, the journalist or media organisation as a whole, are a valued contributor. That's not to say this will be an easy transition. As American writer Clay Shirky, quoted in this book, states in his essay Newspapers and Thinking the Unthinkable: "That is what real revolutions are like. The old stuff gets broken faster than the new stuff is put in its place."

So what does science fiction tell us about the future of the media industry? Well, for starters, science fiction has changed with the times. Clark Kent, Superman, left the Daily Planet "in a huff" in October 2012, and, we are told in chapter 11, is rumoured to be writing a blog or working for a reality show. Spiderman, Peter Parker, left his job as a news photographer with the Daily Bugle to join a think tank, Horizon Labs. So even superheroes have had their reservations about the media industry. On a more positive note, science fiction shows us where the technology of communication may take journalism; augmented reality placing news reports over our everyday experiences and journalists providing access to their streams of consciousness to followers (a slightly chilling thought). 
There's more cause for optimism from science fiction too. Even in the most dystopian of futures painted, there is a place for journalism. "What we can take solace in is that, even in the most disjointed future, we see a demand for journalism and its power-checking role, plus a plethora of technological innovations that will fuel the next generation of journalists" (p. 189). Phew.

References

Ahlers, D. (2006). 'News Consumption and the New Electronic Media'. The Harvard International Journal of Press/Politics 11 (1), pp. 29-52. DOI: 10.1177/1081180X05284317.

Christensen, C. M. (2011). The Innovator's Dilemma: The Revolutionary Book That Will Change The Way You Do Business. New York, NY, U.S.A.: Harper Business. Weimann, G. (1994). The Influentials: People Who Influence People. Albany, NY, U.S.A.: SUNY Press.

Weimann, G. (1991). 'The Influentials: Back to the Concept of Opinion Leaders?' Public Opinion Quarterly 55 (2), pp. 267-279. DOI: 10.1086/269257.

Author

Andy Ridgway is a Senior Lecturer in Science Communication at the University of the West of England in Bristol. Before that, he spent 20 years working as a journalist, most recently as a science journalist. E-mail: andy.ridgway@uwe.ac.uk.

How to cite

Ridgway, A. (2016). 'The new commodities of the new media landscape'. JCOM 15 (04), R01. 